Original Research Article

\title{
Peripheral and central analgesic activity evaluation of ethanolic extract of Vitex Negundo flowers in experimental animals
}

\author{
Yasmeen A. Maniyar, Dasari Sriraj*
}

Department of Pharmacology, S. Nijalingappa Medical College, Navanagar, Bagalkot,

Karnataka, India

Received: 12 September 2017 Accepted: 03 October 2017

\section{*Correspondence to:}

Dr. Dasari Sriraj, Email: drsriraj.dasari@ gmail.com

Copyright: (C) the author(s), publisher and licensee Medip Academy. This is an openaccess article distributed under the terms of the Creative Commons Attribution NonCommercial License, which permits unrestricted noncommercial use, distribution, and reproduction in any medium, provided the original work is properly cited.

\begin{abstract}
Background: Vitex negundo Linn (Family: Verbenaceae), locally known as 'Nirgundi' an important medicinal plant is a woody, aromatic shrub growing to a small tree. It commonly bears tri- or penta-foliate leaves on quadrangular branches, which give rise to bluish-purple coloured flowers in branched tomentose cymes. It has been claimed to possess analgesic activity apart from many medicinal properties. The aim of the present study was to evaluate both the peripheral and central analgesic activity of ethanolic extract of Vitex negundo flowers (EEVNF) in experimental animals.

Methods: Acute toxicity test was done following the Organization of Economic Cooperation and Development guidelines. EEVNF $(100 \mathrm{mg} / \mathrm{kg}, 200 \mathrm{mg} / \mathrm{kg}$, and $400 \mathrm{mg} / \mathrm{kg}$ body weight [b.w.] p.o) was evaluated for peripheral analgesic activity by the acetic acid $(0.7 \%)$ induced writhing test and central analgesic activity by the tail flick method respectively using aspirin $(100 \mathrm{mg} / \mathrm{kg}$ b.w. and $300 \mathrm{mg} / \mathrm{kg}$ b.w.) as the standard drug.
\end{abstract}

Results: EEVNF significantly decreased the number of writhing in writhing test at all the doses $(\mathrm{p}<0.001)$ and increased the reaction time in tail-flick method $(\mathrm{p}<0.001)$ at all the doses when compared to control. EEVNF in the dosage of $400 \mathrm{mg} / \mathrm{kg}$ b.w. produced analgesic effects which was comparable with that of the standard drug aspirin at dose $100 \mathrm{mg} / \mathrm{kg}$ b.w in writhing test and produced greater analgesic activity than that of standard drug aspirin at dose $300 \mathrm{mg} / \mathrm{kg}$ b.w in tail flick method.

Conclusions: EEVNF has significant peripheral and central analgesic activity.

Keywords: Analgesic, Pain, Tail flick, Vitex negundo, Writhing

\section{INTRODUCTION}

Pain has been officially defined as an unpleasant sensory and emotional experience associated with actual or potential tissue damage. It is always a warning signal and primarily protective in nature but often causes a lot of discomfort and lead to many adverse effects. ${ }^{1}$ Pain perception involves two components, the nociceptive component and affective component. Based on a clinical diagnosis of pain it is classified as somatic pain, visceral pain, referred pain, psychogenic/functional pain and neuropathic pain. Pain is a disabling accompaniment of many medical conditions and pain control is one of the most important therapeutic priorities. ${ }^{2}$ Common drugs for pain relief such as aspirin and morphine have been widely used in recent decades. In most instances, these analgesic drugs, particularly opioids and nonsteroidal antiinflammatory drugs (NSAIDs), can only relieve $50 \%$ of the pain in about $30 \%$ of patients. In addition, many of these drugs cause serious side effects. Studies have shown that opiates cause physical dependency, tolerance, and addiction while NSAIDs usually cause gastrointestinal disorders. ${ }^{3}$ On the contrary many medicines of plant origin have been used since ages without any side effects. It is therefore essential that efforts should be made to introduce new medicinal plants to develop more effective analgesics 
without any adverse effects. One among them is Vitex negundo Linn belongs to the family Verbenaceae.

Vitex negundo Linn (Family: Verbenaceae) is a woody, aromatic shrub growing to a small tree. Some common names are in Hindi nirgundi and in Sanskrit as sindhuvara. It commonly bears tri- or pentafoliate leaves on quadrangular branches, which give rise to bluish-purple colored flowers in branched tomentose cymes. It thrives in humid places or along water courses in wastelands and mixed open forests. It is found throughout the greater part of India at warmer zones and ascending to an altitude of $15,00 \mathrm{~m}$ in outer Western Himalayas. ${ }^{4}$

All parts of the plant from root to fruit possess a multitude of phytochemical secondary metabolites which impart an unprecedented variety of medicinal uses to the plant., Vitex negundo has been investigated for antipyretic, analgesic, anti-inflammatory, anticonvulsant, hepatoprotective and bronchial relaxant. ${ }^{7-13}$ Very few studies have been done to evaluate its analgesic activity and no study was done on analgesic activity of flowers of Vitex negundo. Therefore, the present study was undertaken to investigate analgesic activity of ethanolic extract of flowers of Vitex negundo.

\section{METHODS}

\section{Plant material}

Fresh flower powder of Vitex negundo Linn was brought from AGHP Enterprises, Chennai, India in the month of June 2016 which was authenticated by Dr. D. Aravind, Assistant Professor, Botany, National Institute of Siddha, Chennai. The specimen (Voucher number: SNMC/Pharma 009), is preserved for reference in the herbarium of department of Pharmacology, S. Nijalingappa Medical College, Bagalkot, Karnataka, India.

\section{Drugs and chemicals}

Aspirin, $0.7 \%$ acetic acid and normal saline were used in this study.

\section{Instruments}

Analgesiometer, Soxhlet apparatus, digital weighing balance, stopwatch, feeding tube, insulin syringe, mouth gags, tuberculin syringe, Ryle's tube, beaker, glass jar, glass rod.

\section{Preparation of plant extract}

The material was extracted with $80 \%$ ethanol using soxhlet extraction apparatus and it was evaporated to dry at $60^{\circ} \mathrm{C}$. Flower powder $(20 \mathrm{~g})$ of Vitex negundo yeilded $4 \mathrm{~g}$ of crude extract. The solid residues were stored in airtight container and preserved in the refrigerator at $-20^{\circ} \mathrm{C} .{ }^{14}$ From this stock, fresh preparations were obtained whenever required.

\section{Experimental animals}

All the animals were procured from the Central Animal house, S. Nijalingappa Medical College, Bagalkot, India. Swiss albino mice of either gender weighing 25-30g and Albino Wistar rats of either gender weighing 150-250g were selected for the experiment. Pregnant animals, animals with an infection, animals with injuries, deformities were excluded from the study.

Prior to and during study, all the animals were maintained under standard animal house conditions at 12:12 hours dark: light cycle, at temp $25 \pm 2{ }^{\circ} \mathrm{C}$, humidity $35-60 \%$ and other micro and macro environment conditions as suggested by Committee for the Purpose of Control and Supervision of Experiments on Animals (CPCSEA).

All animals were housed in a polypropylene cage covered with a stainless-steel wire mesh and a paddy husk bed, with adequate provision for feed and water. All the animals were maintained on standard laboratory diet (VRK Nutritionals, Pune) and water was provided ad libitum. The study was started after getting the Institutional Animal Ethics Committee approval (IAEC/ S. Nijalingappa Medical College, Bagalkot, India, Reg No.829/AC/04/CPCSEA).

\section{Phytochemical screening}

The freshly prepared extract of the flowers of Vitex negundo was subjected to phytochemical screening tests for the detection of various constituents. ${ }^{15}$

\section{Acute toxicity study}

For acute toxicity study 15 healthy swiss albino mice of either gender weighing $25-30 \mathrm{~g}$ were selected. The animals were treated with increasing doses of EEVNF. The toxicity studies were conducted according to the Organization for Economic co-operation and development (OECD) 423 guidelines. ${ }^{16}$ All the treated animals were observed for any abnormal or toxic manifestations and mortality.

\section{Evaluation of analgesic activity}

\section{Peripheral analgesic activity}

Acetic acid induced writhing test: Following 12 hours fasting 30 healthy Swiss albino mice of 25-30 g were randomly divided into five groups of six animals each. Group I received $0.5 \mathrm{ml}$ of normal saline (control group), Group II received $100 \mathrm{mg} / \mathrm{kg}$ of aspirin (standard group) Group III, IV, V received EEVNF in doses of $100 \mathrm{mg} / \mathrm{kg}$, $200 \mathrm{mg} / \mathrm{kg}$ and $400 \mathrm{mg} / \mathrm{kg}$ b.w (test groups). ${ }^{17}$ All the drugs were given orally. After $1 \mathrm{hr}$ all the animals were given 10 $\mathrm{ml} / \mathrm{kg}$ of $0.7 \% \mathrm{v} / \mathrm{v}$ acetic acid injection intraperitoneally (i.p.). Number of writhings were counted between 5 and 20 mins after acetic acid injection. ${ }^{18}$ 
Percentage inhibition was calculated using the following formula

$\%$ inhibition $=\mathrm{Wc}-\mathrm{Wt} / \mathrm{Wc} * 100$ Where, $\mathrm{Wc}=$ Number of writhings in the control group, $\mathrm{Wt}=$ Number of writhings in test group.

\section{Central analgesic activity}

\section{Tail flick method}

The test was carried out in healthy Albino Wistar rats. 30 animals weighing $150-250 \mathrm{~g}$ were randomly divided into five groups of six animals each after $12 \mathrm{hrs}$ fasting. Group I received $0.5 \mathrm{ml}$ of normal saline (control group), Group II received $300 \mathrm{mg} / \mathrm{kg}$ of aspirin (standard group), and Groups III, IV, V received EEVNF in doses of $100 \mathrm{mg} / \mathrm{kg}$, $200 \mathrm{mg} / \mathrm{kg}$ and $400 \mathrm{mg} / \mathrm{kg}$ b.w (test groups). ${ }^{19}$ All the drugs were given orally. After $1 / 2$ hour, 1 hour, 2 hours, 3 hours the tail flick response was carried out and the reaction time was measured by placing the distal $1 / 3^{\text {rd }}$ of the tail about 1 $\mathrm{cm}$ from the radiant heat source. The time taken by the animal to withdraw the tail was taken as the reaction time. Cut off time was kept as 20-30 sec. The animals showing reaction time of $>20-30$ were excluded from the study. ${ }^{20}$

\section{Statistical analysis}

The stastical data were presented as Mean \pm SEM and results were analysed using One-way analysis of variance (ANOVA) followed by Dunnett's multiple comparison tests. For all the tests 'p' value of 0.05 or less was considered as statistical significance.

\section{RESULTS}

\section{Phytochemical screening}

Phytochemical screening of EEVNF showed that the crude extract contained tannins, alkaloids, terpenoids, flavonoids, sterols, phenolic compounds and proteins.

\section{Acute oral toxicity study}

No adverse effect or mortality was detected in Swiss albino mice at $2 \mathrm{~g} / \mathrm{kg}$ of EEVNF. All the animals were alive, healthy and active during the observational period of 14 days. So, the LD 50 was considered as $>2000 \mathrm{mg} / \mathrm{kg}$.

\section{Acetic acid induced writhing test for evaluating peripheral analgesic activity}

Table 1 shows the results of the peripheral analgesic activity of EEVNF by acetic acid induced writhing test in albino mice. In the present study the test drug at all the doses of $(100 \mathrm{mg} / \mathrm{kg}, 200 \mathrm{mg} / \mathrm{kg}, 400 \mathrm{mg} / \mathrm{kg}$ b.w) of EEVNF and standard drug showed significant reduction in the number of writhings $[31.67 \pm 1.14,23.00 \pm 0.57,14.33 \pm 0.88$ and $12.33 \pm 0.49(\mathrm{p}<0.001)]$ when compared to control $(40.00 \pm 0.57)$. The test drug at the dose of, $100 \mathrm{mg} / \mathrm{kg}$, $200 \mathrm{mg} / \mathrm{kg}$ and $400 \mathrm{mg} / \mathrm{kg}$ produced $20.82 \%, 42.50 \%$ and $64.17 \%$ inhibition of writhings compared to control group. The standard drug aspirin showed $69.17 \%$ inhibition of writhings. The peripheral analgesic activity of test drug at $400 \mathrm{mg} / \mathrm{kg}$ is comparable to that of the standard drug of aspirin at dose $100 \mathrm{mg} / \mathrm{kg}$ b.w.

Table 1: Number of writhings and percentage inhibition of acetic acid induced writhing test.

\begin{tabular}{|llc|}
\hline Groups & M \pm SEM & Percentage of Inhibition (\%) \\
\hline Group I (Control) & $40.00 \pm 0.57$ & - \\
\hline Group II (Aspirin $300 \mathrm{mg} / \mathrm{kg})$ & $12.33 \pm 0.49 * * *$ & 69.17 \\
\hline Group III (EEVNF $100 \mathrm{mg} / \mathrm{kg})$ & $31.67 \pm 1.14 * * *$ & 20.82 \\
\hline Group IV $($ EEVNF $200 \mathrm{mg} / \mathrm{kg})$ & $23.00 \pm 0.57 * * *$ & 42.50 \\
\hline Group V (EEVNF $400 \mathrm{mg} / \mathrm{kg})$ & $14.33 \pm 0.88 * * *$ & 64.17 \\
\hline When compared with control; $* \mathrm{p}<0.05, * * \mathrm{p}<0.01, * * * \mathrm{p}<0.001$. All the values are expressed as mean \pm Standard error of mean $(\mathrm{n}=06)$. \\
\hline
\end{tabular}

Table 2: Mean reaction time (seconds) in tail-flick method.

\begin{tabular}{|lllll|l|}
\hline Groups & 0-hour M \pm SEM & 1/2 hour M \pm SEM & 1-hour M \pm SEM & 2-hour M \pm SEM & 3-hour M \pm SEM \\
\hline Group I control & $11.43 \pm 0.20$ & $11.30 \pm 0.19$ & $11.26 \pm 0.24$ & $11.26 \pm 0.17$ & $11.21 \pm 0.27$ \\
\hline $\begin{array}{l}\text { Group II standard } \\
\text { aspirin (300 mg/kg) }\end{array}$ & $10.66 \pm 0.51$ & $11.46 \pm 0.42$ & $13.84 \pm 0.59^{* *}$ & $16.06 \pm 0.53^{* * *}$ & $18.92 \pm 0.48^{* * *}$ \\
\hline $\begin{array}{l}\text { Group III EEVNF } \\
(100 \mathrm{mg} / \mathrm{kg})\end{array}$ & $11.50 \pm 0.49$ & $12.58 \pm 0.60$ & $13.06 \pm 0.49^{*}$ & $14.37 \pm 0.35^{* * *}$ & $14.74 \pm 0.64^{* * *}$ \\
\hline $\begin{array}{l}\text { Group IV EEVNF } \\
(200 \mathrm{mg} / \mathrm{kg})\end{array}$ & $11.87 \pm 0.43$ & $13.57 \pm 0.59^{* *}$ & $15.63 \pm 0.51^{* * *}$ & $17.44 \pm 0.25^{* * *}$ & $17.72 \pm 0.31^{* * *}$ \\
\hline $\begin{array}{l}\text { Group V EEVNF } \\
(400 \mathrm{mg} / \mathrm{kg})\end{array}$ & $11.76 \pm 0.53$ & $13.97 \pm 0.43^{* *}$ & $16.62 \pm 0.38^{* * *}$ & $18.51 \pm 0.25^{* * *}$ & $19.62 \pm 0.19^{* * *}$ \\
\hline $\begin{array}{l}\text { When compared with control; *p<0.05, **p<0.01, ***p<0.001. All the values are expressed as, Mean } \pm \mathrm{SEM}(\mathrm{n}=06), \mathrm{SEM}=\mathrm{Standard} \\
\text { error of mean. }\end{array}$ & & & \\
\hline
\end{tabular}




\section{Tail flick test for evaluating central analgesic activity}

Table 2 shows the central analgesic activity of the EEVNF by Tail-flick method in Albino Wistar rats. In the present study there was no significant difference between mean reaction time of different groups at 0 hour. Test groups showed increase in the mean reaction time significantly in doses of $200 \mathrm{mg} / \mathrm{kg}, 400 \mathrm{mg} / \mathrm{kg}$ from 1 hour, and in dose of $100 \mathrm{mg} / \mathrm{kg}$ from $2^{\text {nd }}$ hour onward.

The control group showed the mean reaction time of 11.21 $\pm 0.27 \mathrm{sec}$ at $3^{\text {rd }}$ hour. Standard drug aspirin at the dose of $300 \mathrm{mg} / \mathrm{kg}$ b.w body weight showed the mean reaction time of $18.92 \pm 0.48 \mathrm{sec}$ at $3^{\text {rd }}$ hour and test drug in the dose of $400 \mathrm{mg} / \mathrm{kg}$ showed the mean reaction time of $19.62 \pm 0.19 \mathrm{sec}$ at $3^{\text {rd }}$ hour. Test drug at dose of $400 \mathrm{mg} / \mathrm{kg}$ b.w has greater analgesic activity when compared to that of the standard drug aspirin at dose of $300 \mathrm{mg} / \mathrm{kg}$ b.w.

\section{DISCUSSION}

Vitex negundo L. (Verbenaceae) is a hardy plant, flourishing mainly in the Indian subcontinent. All parts of the plant, from root to fruit, possess a multitude of phytochemical secondary metabolites which impart an unprecedented variety of medicinal uses to the plant. The present study was undertaken to investigate peripheral and central analgesic activity of ethanolic extract of flowers of Vitex negundo. Previous studies have shown significant analgesic activity of EEVN leaves. ${ }^{21}$

This study is the first report regarding analgesic activity of EEVN flowers. Anti-nociceptive models like acetic acid induced writhing test and tail flick method were used to evaluate analgesic activity of EEVNF.

Peripheral analgesic activity of EEVNF was evaluated by using writhing test in mice according to the method of Koster et al. ${ }^{2,23}$ Acetic acid-induced writhing reflex is a model of visceral pain which is highly useful for screening analgesic drugs and several chemicals such as phenyl quinone and acetic acid could induce writhing reflex in laboratory animals. Intraperitoneal injection of acetic acid produces pain through activation of chemosensitive nociceptors ${ }^{20}$ or irritation of the visceral surface, which lead to the liberation of histamine, bradykinin, prostaglandins and serotonin. ${ }^{24}$

Also, it has been noted that the level of analgesia in acetic acid-induced models is indicated by the percent reduction in the number of abdominal constrictions. Intraperitoneal injection of $0.7 \%$ glacial acetic acid produced abdominal writhing in this experiment. The extracts derived from flowers of Vitex negundo Linn. exhibited significant analgesic activity in swiss albino mice by inhibiting acetic acid induced writhing. Therefore, EEVNF might be inhibiting synthesis or release of these endogenous substances.
Even though writhing test is very sensitive, it may give false positive results, so tail flick method was conducted to confirm and study the analgesic property in EEVNF.

Central analgesic activity was evaluated by using the tail flick method which is considered to be a spinal reflex induced by heat according to Schumacher et al, and Wolff et al, but could also involve higher neural structures (central analgesic activity). ${ }^{22,25,26}$ Pain is centrally modulated via a number of complex processes including opiate, dopaminergic descending noradrenergic and serotonergic systems. ${ }^{27}$

The significant increase in pain threshold produced by EEVNF at $100 \mathrm{mg} / \mathrm{kg}, 200 \mathrm{mg} / \mathrm{kg}, 400 \mathrm{mg} / \mathrm{kg}$ b.w and aspirin $300 \mathrm{mg} / \mathrm{kg}$ b.w in radiant heat tail flick model may be via central mechanisms involving these receptor systems or via peripheral mechanisms involved in the inhibition of prostaglandins, leukotrienes and other endogenous substances that are key mediators in pain.

The results of the present study have shown that EEVNF produced significant analgesic activity against chemical and thermal models of nociception in mice and rats. Phytochemical analysis of EEVNF showed presence of tannins, alkaloids, terpenoids, flavonoids, sterols, phenolic compounds and proteins.

It is suggested that some flavonoids block both cyclooxygenase and lipoxygenase pathway of the arachidonate cascade at high concentration, while at low concentration only lipoxygenase pathway is blocked. ${ }^{28}$ Flavonoids produces analgesic action by opioid like action. ${ }^{29}$ Furthermore, there are few reports on the role of tannins in analgesic activity. ${ }^{30}$ Previous studies suggested that alkaloids also involve in analgesic action through nonnarcotic action. ${ }^{31,32}$ In the present study flavonoids, tannins and alkaloids might be attributed to the peripheral and central analgesic activities.

\section{CONCLUSION}

In conclusion ethanolic extract of Vitex negundo flowers possess both peripheral and central analgesic activity. Further pharmacological analysis of the extract is needed to isolate and characterize the active ingredient responsible for its analgesic effect. The plant can be recommended for the further studies to isolate the active ingredients.

\section{ACKNOWLEDGEMENTS}

Authors would like to thank anonymous reviewers for their valuable comments in improvising the research.

Funding: No funding sources

Conflict of interest: None declared

Ethical approval: The study was approved by the Institutional Ethics Committee 


\section{REFERENCES}

1. Raquibul SM, Hossain MM, Aktar R, Jamila M, Mazumder MEH, Alam MA, et al. Analgesic activity of the different fractions of the aerial parts of Commenila Benghalensis Linn. Int $\mathrm{J}$ Pham. 2010;6(1):63-7.

2. Rang HP, Ritter JM, Flower RJ, Henderson G. Analgesic drugs. Rang and Dale's Pharmacology. $7^{\text {th }}$ ed. Spain: Elsevier ltd; 2012:503.

3. Hanson GR, Venturelli PJ, Fleckenstein AE. Drugs and Society, Jones and Bartlett, Boston, Mass, USA, $10^{\text {th }}$ edition, 2009.

4. Nair CKN, Mohanan N. Medicinal Plants in India with special reference to Ayurveda. Delhi, India: NAG Publisher; 1998:443.

5. Vishwanathan AS, Basavaraju R. A Review on Vitex Negundo L: a medicinally important plant. EJBS 2010;3:30-42.

6. Renuka Devi P, Krishna Kumari S, Kokilavani C. Effect of Vitex Negundo leaf extract on the free radicals' scavengers in complete freund's adjuvant induced Arthritic rats. Indian J Clin Biochem. 2007;22(1):143-7.

7. Tirumalasetty J, Sheikh U, Chandrasekhar N, Kishan PV, Rasamal K. Evaluation of antipyretic activity of alcoholic extract of vitex negundo leaves in PGE1 induced pyrexia model in albino rats. J Chem Pharm Res. 2012;4(6):3015-9.

8. Telang RS, Chatterjee S, Varshneya C. Studies on analgesic and anti-inflammatory activities of Vitex negundo Linn. Indian J Pharmacol. 1999;31:363-6.

9. Jana U, Chattopadhyay RN, Shaw BP. Preliminary studies on anti-inflammatory activity of Zingiber officinale Rose, Vitex negundo Linn and Tinospora Cordifolia (wild) miers in albino rats. Indian J Pharmacol. 1999;31:232-3.

10. Ravishankar B, Bhaskaran NR, Sasikala CK. Pharmacological evaluation of Vitex negundo (Nirgundi) leaves. Bull Medico-Ethno Bot Res. 1985;6:72-92.

11. Gupta M, Mazumder UK, Bhawal SR. CNS activity of Vitex-negundo Linn in mice. Indian J Exp Biol. 1999;37:143-6.

12. Avadhoot Y, Rana AC. Hepatoprotective effect of Vitex negundo against carbon tetrachloride induced liver damage. Arch Pharm Res. 1991;14:96-8.

13. Nair AM, Saraf MN. Inhibition of antigen and compound 48/80 induced contraction of guinea pig trachea by ethanolic extract of the leaves of Vitex negundo linn. Indian J Pharmacol. 1995;27:230-3.

14. Erturk O. Antibacterial and antifungal activity of ethanolic extract from eleven spice plants. Biol Bratislava. 2006;61(3):275-8.

15. Harbone JB. Phytochemical methods. A guide to modern techniques of plant analysis. $2^{\text {nd }} \mathrm{ed}$. London, Chapman and Hall; 1984:274-284.

16. OECD Guidance Document on Acute Oral Toxicity. Environmental Health and Safety Monograph Series on Testing and Assessment, 2001. Available at: https://ntp.niehs.nih.gov/iccvam/suppdocs/feddocs/oe cd/oecd-gd24.pdf.

17. Rajveer CH, Swarnalatha CH. Synthesis of 6Bromooxo quinazoline derivatives and their pharmacological activities. Int $\mathrm{J}$ Chem Res. 2010;1(1):21-4.

18. Sharma US, Sharma UK, Sutar N, Shahnawaj A, Kumar KP. Evaluation of analgesic, anti-pyretic and anti-inflammatory activities of Andropogan muricatus root extract. J Pharm Res. 2010;3(7):1652-4.

19. Panthong A, Norkaew P, Kanjanapothi D, Taesotikul T, Anantachoke N, Reutrakul V. Anti-inflammatory, analgesic and antipyretic activities of the extract of gamboge from Garcinia hanburyi Hook f. J Ethnopharmacol. 2007;111(2):335-40.

20. Indumathy $S$, Kavimani S. Analgesic activity of angiotensin antagonists. Afr J Pharm Pharmacol. 2011;5(2):194-8.

21. Telang RS, Chaterjee S, Varshneya C. Studies on analgesic and anti-inflammatory activities of vitex negundo Linn. Indian J Pharmacol. 1999;31(5):363-6.

22. Koster R, Anderson M, de Beer EJ. Acetic acid for analgesic screening. Fed Proc. 1959;18:138.

23. Taber RI, Greenhouse DD, Rendell JK, Irwin S. Agonist and antagonist interactions of opioids on acetic acid-induced abdominal stretching in mice. $\mathrm{J}$ Pharmacol Exp Ther. 1969;169(1):29-38.

24. Schumacher GA, Goodell H, Hardy JD, Wolff HG. Uniformity of the pain threshold in man. Science. 1940;92(2379):110-2.

25. Wolff HG, Hardy JD, Goodell H. Studies on pain. Measurement of the effect of morphine, codeine, and other opiates on the pain threshold and an analysis of their relation to the pain experience. J Clin Investn. 1940;19(4):659-80.

26. Medhi B, Prakash A. Practical Manual of Experimental and Clinical Pharmacology. $1^{\text {st }}$ ed. Chandigarh: Jaypee; 2010:76-81.

27. Mishra D, Ghosh G, Kumar PS, Panda PK. An experimental study of analgesic activity of selective COX-2 inhibitor with conventional NSAIDs. Asian J Pharm Clin Res. 2011;4(1):78-81.

28. Pourmotabbed A, Farshchi A, Ghiasi G, Khatabi PM. Analgesic and anti-inflammatory activity of Teucrium chamaedrys leaves aqueous extract in male rats. Iran $\mathbf{J}$ Basic Med Sci. 2010;13(3):119-25.

29. Thirugnanasambantham $P$, Viswanathan S, Mythirayee C, Krishnamurty V, Ramachandran S, Kameswaran L. Analgesic activity of certain flavone derivatives: a structure-activity study. J Ethnopharmacol. 1990;28(2):207-14.

30. Chakraborty A, Devi RK, Rita S, Sharatchandra K, Singh TI. Preliminary studies on anti-inflammatory and analgesic activities of Spilanthes acmella in experimental animal models. Indian $\mathbf{J}$ Pharmacol. 2004;36(3):140-50.

31. Goji AD. A study of the anti-inflammatory and analgesic activities of aqueous extract of Nauclea latifolia leaves in rodents. Asian $\mathrm{J}$ Med Sci. 2010;2(6):244-7. 
32. Farouk L, Laroubi A, Aboufatima R, Benharref A, Chait A. Evaluation of the analgesic effect of alkaloid extract of Peganum harmala L: Possible mechanisms involved. J Ethnopharmacol. 2008;115(3):449-54.
Cite this article as: Maniyar YA, Sriraj D.

Peripheral and central analgesic activity evaluation of ethanolic extract of Vitex Negundo flowers in experimental animals. Int J Basic Clin Pharmacol 2017;6:2701-6. 